\title{
New initiative launched to support research in Africa
}

Newton Kumwenda knows firsthand the barriers to conducting biomedical research in Africa's poorest countries.

As an epidemiologist at the University of Malawi, he has produced more than a dozen papers on HIV within the last two years. He can find qualified nurses and doctors for his clinical trials—even amid a shortage. But, he says, "it's very difficult to get people at the scientific level-people who can analyze the data and come up with new scientific questions." What's more, universities such as his often do not have the capacity to administer scientific grants, and the best researchers often leave the country.

That could begin to change with a new program announced by The Wellcome Trust on 2 July, dubbed the African Institutions Initiative. The London-based charity will invest $\mathfrak{E 3 0}$ million ( $\$ 50$ million) over five years in the program, which aims to bolster the capacity for scientific research at African institutions, mainly universities.

Seven research consortiums, picked out of 88 initial applications, will use the funds to bolster research activities in a range of fields, from infectious disease to environmental health. Each

\section{Medical research charities brace for economic impact}

The majority of charities that fund medical research are bracing for the impact of the current economic recession, and they're making an early call for help.

According to a survey released on 27

May by the UK-based Association of Medical Research Charities (AMRC), threequarters of the organization's affiliated charities expect the economic downturn to have a marked impact on their income. A quarter of the charities expect to cut funding for research between $10 \%$ and $40 \%$ this year.

Income sources for the charities are many and varied, thus few of the organizations have good estimates as to how much their income will drop for the 2009-2010 year, said Sophie PetitZeman, head of external relations for the AMRC.

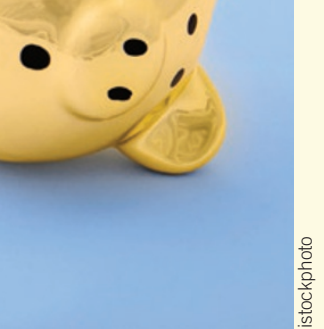

Tough times: Nonprofits ask for help
The biggest drop probably won't come from public citizens feeling the pinch. According to the UK-based Institute of Fundraising, public donations for all charities are only down 3-4\%. In the US, meanwhile, information gathered by the Center on Philanthropy at Indiana University shows that public donations have been affected very little by past recessions.

The most substantial impact will instead come from a devaluing of investments. Many medical research charities survive primarily on this income.

In the US, charities provide about 3\% of the amount spent on medical research (J. Am. Med. Assoc. 294, 1333-1342; 2005 ), whereas $30 \%$ is delivered by the National Institutes of Health. In the UK, however, the amount from charities is on par with that distributed by the government.

Along with its call for continued public support, the AMRC is requesting that the UK government increase funding for medical research while offering tax breaks and regulatory initiatives that would make funding easier, Petit-Zeman said.

"We know funding is down," says Ron Maclnnis, director of policy and programs at the International AIDS Society. "But, with the way grants and funding work, right now we're working with money from a year and a half ago when the giving was good. We have a time lag, and we have to take action now to take advantage of that."

Stu Hutson, Gainesville, Florida consortium consists of several universities and research institutions within Africa, which have forged partnerships with universities in the UK, Australia, Europe or the US.

Kumwenda will lead one such consortium, which will receive $\mathfrak{E} 6$ million to boost research at the University of Malawi, the University of Zambia and the University of Zimbabwe. Much of the money will go to funding individual research projects and constructing education programs for masters, $\mathrm{PhD}$ and postdoctoral researchers.

"Our main objective is to build a critical mass of research scientists," says Kumwenda. Scientists will be trained at these three universities, but outside collaborations will increase access to mentorship, advice and resources. These collaborators include several universities in the UK, the University of Botswana and The University of Cape Town in South Africa, which have better research infrastructure. The consortium will also provide administration to help scientists win competitive grants from outside sources.

Jimmy Whitworth, who heads the new initiative at the Wellcome Trust, says that international donors have in the past focused more on funding stand-alone research centers instead of universities. "There is a real need to bring the teaching and the research and clinical services together," he says. "At the moment, research is done elsewhere, and it's not seen as a mainstream career."

The new initiative dovetails with other efforts to boost research in Africa and other lowand middle-income nations. These include a long-running program at the World Health Organization, the Special Program for Research and Training in Tropical Diseases, and the European and Developing Countries Clinical Trials Partnership (EDCTP), a program that supports clinical trials for HIV/AIDS, malaria and tuberculosis.

Charles Mgone, the director of the EDCTP, helped review the applications for the new Wellcome Trust initiative; "we are trying to synergize how we work together," he says. He praises both initiatives for "empowering African governments and African scientists to empower themselves."

Other institutions are making similar moves. On 10 June the US National Institutes of Health announced a \$34 million program to fund ten research and training centers based in lowor middle-income countries to prevent and control chronic diseases, including one center in Africa, at the University of Cape Town.

Charlotte Schubert, Washington, DC 